\title{
HARMONIZATION OF ASEAN LAW IN SOLVING ENVIRONMENTAL ISSUES FOCUSING ON ENVIRONMENTAL IMPACT ASSESSMENT LAW IN THAILAND
}

\author{
Amnat Wongbandit \\ ${ }^{1}$ Faculty of Law, Thammasat University, Thailand \\ E-mail:wongban@tu.ac.th
}

\begin{abstract}
As the ASEAN Economic Community was formed, in principle there should be a free flow of economic activities, capital, labor and other things across borders within this community for the benefit of all in the region but in reality, there are still some legal impediments to the achievement of this goal. Harmonization of law of ASEAN countries would help to ease this problem. The same is also applicable to the problems of environmental protection as different laws in different jurisdictions could lead to the situation that polluters would certainly try to stay away from a country with strict environmental law and move their business to where the law is not that strict, or law enforcement is quite weak.Environmental impact assessment has played a very important role in environmental protection because it can be used as a method to predict what would be an environmental consequence of carrying out particular project or activity and offer how negative impacts could be prevented or mitigated. This article therefore would like to present the environmental impact assessment law in Thailand which consists of several interesting issues that could be the subjects of debate as to whether it would be possible or practical to harmonize ASEAN laws on such issue
\end{abstract}

Keywords: ASEAN Economic Community, ASEAN laws, Environmental impact assessment

\section{Introduction}

\section{Environmental Impact Assessment Law}

The Enhancement and Conservation of National Environmental Quality Act, 1992 ${ }^{1}$, amended in 2018 (ECNEQA) $^{2}$, is the key legislation governing environmental impact assessment in Thailand. It contains only main legal principles such as who has power to specify activities or projects that need to conduct an environmental impact assessment

\footnotetext{
${ }^{1}$ Government Gazette, Volume 107, Chapter 37, page 1, April 4, 1992.

${ }^{2}$ Government Gazette, Volume 135, Chapter 27 Kor, page 29, April 19, 2018.
}

before activity or project implementation, and what steps should be taken in preparing, submitting and reviewing an environmental impact assessment report. The details on these matters are usually elaborated by subordinate law.

It should be noted that the ECNEQA does not govern strategic environmental assessment (SEA) but it focuses only on environmental impact assessment (EIA). However its Section 47 states that if SEA has already been conducted in according to any 
other laws or regulations ${ }^{3}$, such SEA shall also be taken into consideration in preparing an EIA report. As a result, this article would mention only EIA.

\section{Results and Analysis}

\section{Projects That Need to Conduct} Environmental Impact Assessment

According to Section 48 of the ECNEQA, the Minister of Natural Resources and Environment, subject to the approval of the National Environment Board, has power to make an notification that projects, activities or operations of the government or that need permission from the government must prepare an environmental impact assessment report before their implementation if it causes environmental impacts or is likely to cause severe adverse effects upon natural resources, environmental quality, health, amenity, quality of life or any important interest of people, community or environment. Projects, activities or operations that need to comply with this provision could be carried out by government agencies or the private sector, which needs to obtain permission from government agencies.

\footnotetext{
${ }^{3}$ Despite the fact that the Office of National Economic and Social Development Board has been trying to propose a set of rules concerning SEA, there has been no law directly addressing what policy, plan or program needs to have SEA and how to prepare, submit and review an SEA report.
}

The projects, activities or operations listed by the ministerial notifications can be divided into two categories; the first group consisting of projects that cause regular environmental impacts, and the second group consisting of projects that are likely to cause severe impacts upon natural resources, environment, health, amenity and communities.

The first group of projects, activities or operations is as follows;

(1) Mining under the mineral law;

(2) Petroleum industry;

(3) Petroleum and fuel pipeline system project;

(4) Industrial estates according to the law concerning industrial estates or projects similar to industrial estates or industrial land allocation projects;

(5) Petrochemical industry using a chemical process in production;

(6) Petroleum refinery industry;

(7) Natural gas separation or reforming industry;

(8) Chlor-alkaline industry using Sodium Chloride as raw material to produce Sodium Carbonate, Sodium Hydroxide, Hydrochloric Acid, Chlorine, Sodium Hypo-Chloride and Bleaching powder;

(9) Cement industry;

(10) Pulp industry;

(11) Industry using a chemical process in producing an active substance or pesticides; 
(12) Chemical fertilizer industry using a chemical process;

(13) Sugar industry;

(14) Iron or steel industry;

(15) Mineral smelting or dressing industry, or metal melting industry, which are not iron or steel industry;

(16) Liquor and alcohol industry including beer and wine;

(17) Waste treatment plants according to law concerning factories;

(18) All thermal power plants except that using garbage as fuel;

(19) Expressway according to the law concerning Expressway and Rapid Transit Authority of Thailand or similar projects;

(20) Highways or roads according to the law concerning highways, which pass through certain areas such as wildlife sanctuaries and national parks;

(21) A public transit system on rail;

(22) Wharf;

(23) Marinas;

(24) Coastal land reclamation;

(25) Construction or the expansion of structure in the sea such as groins, jetties or offshore breakwaters;

(26) Air transportation projects; construction or expansion of commercial airports or runways or water airports;

(27) Buildings located adjacent to rivers, coastlines, lakes or beach, or near or in national parks or historic parks, which is likely to cause adverse impacts upon environmental quality. It also includes buildings for retail and wholesale business, and private office buildings;

(28) Residential or commercial land allocation according to the law concerning land allocation;

(29) Hospitals or nursing homes according to the law concerning medical services;

(30) Hotels or resorts according to the law concerning hotels;

(31) Buildings with separate living units according to the law concerning building control;

(32) An irrigation area of at least 12,800 hectares;

(33) All projects located in areas specified by the Cabinet resolution as Class 1 Watershed;

(34) Inter-diversions between main river basins and between international rivers;

(35) Watergates in main rivers ${ }^{4}$

It should be noted that not all the projects, activities or operations mentioned in the previous paragraph need to prepare an EIA report but their sizes or production capacity

\footnotetext{
${ }^{4}$ Ministry of Natural Resources and Environment's Notification on Types and Sizes of Projects or Activities Which are Required to Prepare an Environmental Impact Assessment Report, and Criteria, Methods, Practice and Guidelines for Preparing an Environmental Impact Assessment Report, Government Gazette, Volume 129, Special Chapter 97 Ngor, page 1, June 20, 2012. It has been amended by the Ministerial Notifications, dated 20 July 2012, 6 February 2013, 11 November 2013, 27 October 2014, 19 August 2015, 17 November 2015, and 22 November 2016.
} 
specified by the ministerial notification must be taken into consideration. ${ }^{5}$

The second group of project, activities or operations is as follows;

(1) Coastal and lake land reclamation off the shoreline except for beach rehabilitation;

(2) Following mining according to the law on minerals;

2.1 Underground mining the structure of which is designed to be self-destructive after stopping operation without supporting structure to prevent a tunnel collapse

2.2 Lead, zinc and other metals mines using cyanide, mercury or lead nitrate in a production process, or mining of other metals having arsenopyrite as associated mineral

2.3 Coal mines from which coal is taken out by vehicles

\subsection{Sea mining}

(3) Industrial estates under the law on industrial estates or projects similar to industrial estates;

(4) Upstream and intermediate petrochemical industry;

(5) Ore smelting or metal melting industry, especially iron, copper, gold, zinc and lead smelting industry;

(6) Production, disposal and modification of radioactive substance;
(7) Central waste treatment plants or factories that bury garbage or unused materials under the law concerning factories, which burn or bury hazardous waste except burning in a cement oven that uses hazardous waste as substituted fuel or additional fuel;

(8) Air transport projects with the construction or expansion of runway of at least 3,000 meters;

(9) Wharf;

(10) Dams or reservoirs;

(11) Thermal power plants using coal, biomass or natural gas as fuel and nuclear power plants;

(12) Coke production industry ${ }^{6}$

Although some projects or activities in the second group may also appear in the first group, those in the former are usually larger in size or higher in production capacity than their counterparts in the latter.

\section{Who are Eligible to Prepare an EIA Report?}

After a particular project is required to have an environmental impact assessment,

\footnotetext{
${ }^{6}$ Ministry of Natural Resources and Environment's Notification on Types, Sizes and Practice of Projects or Activities likely to Cause Severe Impacts upon Communities in terms of Environmental Quality, Natural Resources and Health, which the Government Agencies, State Enterprises or Private Sector concerned have to Prepare an Environmental Impact Assessment, Government Gazette, Volume 127, Special Chapter 104 Ngor, page 34, August 31, 2010. It has been amended by some ministerial notifications on 19 November 2010, 5 November 2015 and 25 March 2016.
} 
who is eligible to prepare an EIA report for that project? Section 51/4 of the ECNEQA states that the Minister of Natural Resources and Environment, subject to the approval of the National Environment Board, may require that an EIA report be prepared or certified by a person holding a license for preparing the EIA report. It is the discretion of the Minister as to whether or not to set up that requirement but in practice the Minister exercised his power by issuing the Ministerial Notification on Determining the Types and Sizes of Projects or Activities that Need to Prepare an Environmental Impact Assessment Report, and Criteria, Methods, Practices and Guidelines for Preparing the Report, dated April 24, 2012. ${ }^{7}$

Its Article 4, paragraph 2, states that the preparation of an EIA report shall be done by a person having a license as an expert in environmental impact assessment. It means that if a project proponent wants to prepare the report by itself, it must have a license for this purpose but in practice most project proponents hire a firm with license to prepare the reports.

According to paragraph 2 of Section 51/4 of the ECNEQA, the details of how to apply for a license to prepare an EIA report, criteria for license issuing, qualifications of applicant, license renewal, the replacement of original license, and the suspension and

\footnotetext{
${ }^{7}$ Supra note 4, id.
}

revocation of license shall be prescribed by ministerial regulation. Although no regulation on such matters has been issued under the ECNEQA, the old Ministerial Regulation No.2, $1984,{ }^{8}$ issued by the former Ministry of Science, Technology and Energy $^{9}$ under the already repealed Enhancement and Conservation of National Environmental Quality Act, 1975, is still effective. According to this Regulation, Article 1, the following persons are eligible to apply for a license as an expert in environmental impact assessment.

(1) Higher education institutions or research institutes having legal personality under Thai law

(2) Juristic persons registered under Thai law;

a. Registered partnerships, all partners of which have Thai nationality;

b. Limited partnerships, all partners with unlimited liability of which have Thai nationality and at least $51 \%$ of capital of which belongs to natural persons having Thai nationality;

c. Companies, at least half of directors of which has Thai nationality, and at least $51 \%$ of capital of which belongs to natural persons having Thai nationality.

(3) Juristic persons registered under international law provided that their EIA

\footnotetext{
${ }^{8}$ Government Gazette, Volume 101, Chapter 184, Special Issue, page 1, December 12, 1984

${ }^{9}$ This power now belongs to the Ministry of Natural Resources and Environment.
} 
reports are jointly prepared by juristic persons under (1) and (2), which hold a license for preparing such reports

(4) State enterprises established by law are eligible to apply for a license to prepare EIA reports for their business only.

(5) Mining Industry Council under the law concerning mining industry council

It should be noted that applicants in (1) and (2) must have their headquarters or business offices in Thailand. Regarding to applicants in (2) and (3), their objects must include research business and consulting services.

According to Article 4 of the Ministerial Regulation No.2, 1984, a person holding a license shall employ the following persons throughout the duration of the license;

(1) At least one full-time expert with following qualifications;

a. Obtaining at least bachelor degree or equivalence in one of the following areas;

1. Environment, ecology or sanitation;

2. Environmental or sanitary engineering;

3. Environmental economics.

b. Having experience in enhancing and conserving environmental quality determined by the National Environment Board;

c. Never having part in preparing $\mathrm{n}$ false EIA report unless it was done three years or more after a license holder that prepared the false report was deprived of his license.

(2) At least three full-time employees helping to prepare the report and they must have the following qualifications;

a. Obtaining at least bachelor degree or equivalence in natural science, engineering or social science;

b. Never having part in preparing a false EIA report unless it already passes three years or more from the date that a license holder preparing the false report was deprived of his license.

The license is valid for five years from the date of issuance.

\section{Contents of an EIA Report}

In preparing an EIA report, a project proponent must comply with guidelines issued by the Minister of Natural Resources and Environment. The contents of the report are slightly different between projects having environmental impacts and those likely to cause severe adverse effects upon natural resources, environmental quality, health, amenity, quality of life, or any important interest of people, community or environment.

3.1 Projects Having Environmental Impacts

The Minister issued the Notification on Types and Sizes of Projects or Activities, Which are Required to Prepare an Environmental Impact Assessment Report, and Criteria, Methods, Practice and 
Guidelines for Preparing an Environmental Impact Assessment Report, ${ }^{10}$ dated April 24, 2012, which states that an EIA report consists of two parts; summary report and main report.

\subsubsection{Summary Report}

The summary report on environmental impact assessment must include the following data and information;

(1) Type and size of project and relevant activities

(2) Project site with pictures and location maps including maps displaying environment compositions in the potentially affected area at the scale of $1: 50,000$ or at a proper scale.

(3) Options for a project site selection, method of implementation as well as reasons and factors to be taken into consideration

(4) Display of major environmental impacts, preventive, remedial and monitoring measures according to the format below. ${ }^{11}$

\begin{tabular}{|l|l|l|l|}
\hline $\begin{array}{l}\text { Environment } \\
\text { Compositions } \\
\text { and Various } \\
\text { Values }\end{array}$ & $\begin{array}{l}\text { Major } \\
\text { Environ } \\
\text {-mental } \\
\text { Impacts }\end{array}$ & $\begin{array}{l}\text { Preventi } \\
\text { ve and } \\
\text { Remedi } \\
\text { al } \\
\text { Measure } \\
\text { s for } \\
\text { Solving } \\
\text { Environ } \\
\text {-mental } \\
\text { Impacts }\end{array}$ & $\begin{array}{l}\text { Monit } \\
\text { oring } \\
\text { Measu } \\
\text { res for } \\
\text { Enviro } \\
\text { nment } \\
\text { ampact } \\
\text { s }\end{array}$ \\
\hline $\begin{array}{l}\text { Physical } \\
\text { environmental } \\
\text { resources }\end{array}$ & & & \\
\hline $\begin{array}{l}\text { Biological } \\
\text { environmental } \\
\text { resources }\end{array}$ & & & \\
\hline Use value & & & \\
\hline $\begin{array}{l}\text { Values for } \\
\text { quality of life }\end{array}$ & & & \\
\hline
\end{tabular}

\subsubsection{Main Report}

The main report for environmental impact assessment shall contain the following essential elements;

(1) Introduction: it should include the rationale and objectives of the project, the objectives and scope the report as well as methodology of study.

(2) Project site: there must be pictures and location maps including maps displaying environment compositions in the potentially affected area at the scale of $1: 50,000$ or at a proper scale.

(3) Details of the project: it includes the details capable of demonstrating a clear overall picture of the project such as the project type and size, a project operation method or relevant activities as well as a land use plan in the project by indicating proper directions and scale.

(4) Present environment: it shall display the details with pictures of natural resources and physical and biological environment by classifying them into recoverable and non-recoverable resources, values for quality of life, current problems of the project site with maps of the project environment, and land use around the project site as well as within areas probably affected by the project operation both in long-term and short-term.

(5) Assessment of options and potential impacts probably arising from the project. 
(5.1) Selection of options: the report shall offer all possible project sites and methods of implementation compatible with the project objectives, how to achieve the objectives, the necessity of having or not having the project, options for preventive and remedial measures, and the most suitable option for project implementation with attached reasons and necessity.

(5.2) Environmental impact assessment: the assessment shall include both direct and indirect impacts possibly caused by the project upon natural resources and environment as well as values in (4) by classifying them into recoverable and non-recoverable resources. It shall also compare impacts probably caused by all the options.

(6) Preventive and mitigation measures and compensation: it shall provide details on measures for preventing and mitigating impacts arising in (5), and compensation plan if damage inevitably occurs.

(7) Monitoring measures: it shall provide proper measures and plans for monitoring environmental impacts, which would also be used for monitoring after the operation of the project.
(8) Table summarizing major environmental impacts with preventive and mitigating measures $^{12}$

\subsection{Projects Likely to Cause Severe Adverse Impacts}

The contents of an EIA report for projects likely to cause severe adverse effects is prescribed by the Ministry of Natural Resources and Environment's Notification on Criteria, Methods, Practice and Guidelines for Preparing an Environmental Impact Assessment Report for Projects or Activities likely to Cause Severe Impacts upon Communities in terms of Environmental Quality, Natural Resources and Health, August 22, 2017, ${ }^{13}$ which stipulates that the report consists of a summary and main report.

\subsubsection{Summary Report}

The summary report consists of the followings data and information;

(1) Details of the project and relevant activities

(2) Project site with pictures and location maps including maps displaying environment compositions in the potentially affected area at the scale of $1: 50,000$ or at a proper scale.

(3) Options for a project site selection, method of implementation as well as

\footnotetext{
${ }^{12} \mathrm{Id}$.

${ }^{13}$ Government Gazette, Volume 134, Special Chapter 228 Ngor, page 5, September 18, 2017
} 
reasons and factors to be taken into consideration.

(4) Display of major environmental impacts, preventive, remedial and monitoring measures according to the format below.

\begin{tabular}{|c|c|c|c|}
\hline $\begin{array}{l}\text { Environ- } \\
\text { ment } \\
\text { Compositi } \\
\text { ons and } \\
\text { Various } \\
\text { Values }\end{array}$ & $\begin{array}{l}\text { Major } \\
\text { Enviro } \\
\mathrm{n}- \\
\text { mental } \\
\text { Impacts }\end{array}$ & $\begin{array}{l}\text { Preventive } \\
\text { and } \\
\text { Remedial } \\
\text { Measures for } \\
\text { Solving } \\
\text { Environmen- } \\
\text { tal Impacts }\end{array}$ & $\begin{array}{l}\text { Monitori } \\
\text { ng } \\
\text { Measures } \\
\text { for } \\
\text { Environ } \\
\text { menttal } \\
\text { Impacts }\end{array}$ \\
\hline $\begin{array}{l}\text { Physical } \\
\text { environme } \\
\text { ntal } \\
\text { resources }\end{array}$ & & & \\
\hline $\begin{array}{l}\text { Biological } \\
\text { environme } \\
\text { ntal } \\
\text { resources }\end{array}$ & & & \\
\hline Ecosystem & & & \\
\hline $\begin{array}{l}\text { Use value } \\
\text { for human } \\
\text { being }\end{array}$ & & & \\
\hline $\begin{array}{l}\text { Values for } \\
\text { quality of } \\
\text { life }\end{array}$ & & & \\
\hline
\end{tabular}

(5) Summary of severe adverse impacts

(6) upon communities in terms of environmental quality, natural resources and health with supporting reasons and criteria $^{14}$

\subsubsection{Main Report}

The contents of the main EIA report of projects likely to cause severe adverse impacts upon communities under 4.2 are quite similar to that of projects having environmental impacts under 4.1 but there are some slight differences. With respect to the topic "present environment," the main report of the projects under 4.2 needs to add information on social conditions and health of those likely to be affected by the projects. In assessing all available options for selecting the project, the report shall additionally take into consideration data on the social conditions and health of people likely to be affected by the projects. Moreover, in assessing environmental impacts, the report shall also include the assessment of the health of such people, and public hearings on the report must be organized in accordance with what is prescribed in the 2017 Ministerial Notification. ${ }^{15}$ Another important point in the report is to elaborate what would be severe adverse impacts possibly arising from the projects. Regarding preventive and mitigation measures, compensation and monitoring, the report must add measures to prevent, mitigate and monitor relevant social and health problems.

\section{Public Participation}

Similar to what has been practiced in many countries, the environmental impact assessment process in Thailand needs public participation so that it would be carried out with transparency and opportunities to listen to all stake holders. Section 48 of the ECNEQA states clearly that such a process shall be conducted with public participation

\footnotetext{
${ }^{15} I d$.
} 
to be prescribed by the Minister of Natural Resources and Environment with the approval of the National Environment Board.

Regarding the preparation of an EIA report of a project or activity having environmental adverse impacts, the Ministry of Natural Resources and Environment issued the Notification on Types and Sizes of Projects or Activities, Which are Required to Prepare an Environmental Impact Assessment Report, and Criteria, Methods, Practice and Guidelines for Preparing an Environmental Impact Assessment Report, dated April 24, 2012, ${ }^{16}$ which states, among other things, that the report must be prepared with public participation but the Notification fails to elaborate how the public could participate in this process. In practice a project proponent would have to find out what should be a proper means for the public participate in an environmental impact assessment process. Since in theory there are so many methods for public participation, it sometime could lead to a dispute in court as to whether the proponent of a particular project allowed proper public participation in preparing an EIA report. For instance the project proponent may claim that a public hearing was already organized in a city center for the public to voice their concerns on the proposed project but some local people might argue that the public hearing

\footnotetext{
${ }^{16}$ Supra note 4 , id.
}

should have been held within their community or every person possibly affected by the project should have been interviewed.

When an environmental impact assessment for a project likely to cause severe impacts upon health, communities, natural resources or environment is examined, it must comply with the Ministerial Notification on Criteria, Methods, Practice and Guidelines for Preparing an Environmental Impact Assessment Report for Projects or Activities likely to Cause Severe Impacts upon Communities in terms of Environmental Quality, Natural Resources and Health, August 22, 2017, ${ }^{17}$ which states that public participation shall be organized in a way prescribed by the Notification.

According to the Notification, public participation would happen in three stages; scoping, report preparation and report review.

\section{a. Scoping}

Before conducting an environmental impact assessment, "scoping" is a very crucial step to decide the scope of assessment or what issues to be included in the assessment as there is limited time and resources for each project which makes it impossible to study all minor and significant issues. Participation from local or potentially affected people would effectively help to

${ }^{17}$ Supra note 13 , id. 
identify which issues are important to them and should be addressed by the assessment report.

The Notification requires a project proponent to hold a public hearing for determining the scope of environmental impact assessment. The Office of Natural Resources and Environmental Policy and Planning (ONREPP), the National Health Commission Office (NHCO) and the public must be informed at least one month in advance. The project documents containing the rationale, necessity, funding sources and operation of project must be disclosed to the public for considering at least 15 days. The disclosure also includes preliminary data concerning factors likely to cause impacts upon the environment and health, and the proposed draft of the scope of the assessment. A proper registering system must be arranged in advance for those who would like to come to the venue and comment on the proposed scope and guidelines for environmental impact assessment.

The public hearing must be organized when is convenient to the persons concerned and public to express their views. They must have at least two hours in voicing their concerns and that period must not be less than half of the entire time spent in the hearing. After that the project proponent must allow the public to express their views not fewer than 15 days and by at least two channels in communication. Finally the project proponent would have to summarize all the opinions and answers and submit them with scope and guidelines for environmental and health impact assessment to the ONREPP for acknowledgement and NHCO for further public distribution. ${ }^{18}$

\section{b. Report Preparation}

Prior to writing an EIA report, some data must be collected and then used in environmental and health impact assessment. The Notification specifies how public participation would be taken into this assessment process. In surveying or listening to the opinions of the public or stakeholders, the project proponent must disclose the details of the projects such as the type, size and production capacity of the project, pollution possibly caused by project operation, water and land receiving waste from the project, factors affecting health, guidelines for environmental and health impact assessment, measures for preventing and mitigating adverse effects, expected date of project operation, time, date and venue for public hearing and issues to be discussed.

In collecting views or data from the people or stakeholders, one or more of the followings methods could be used;

1) Personal interview;

2) Views delivered through mail, telephone, facsimile, data networks and others;

${ }^{18} I d$. 
3) People and stakeholders can acquire data and information concerning the project from and voice their concerns to responsible government agencies;

4) Focus group meeting;

5) Workshop; and

6) Meeting of representatives of relevant people or stakeholders.

After the collection of views mentioned earlier is completed, the project proponent is obliged to summarize all positive and negative opinions within 15 day. Such a summary and the draft EIA report shall be displayed for at least 15 days at the Provincial Office of Natural Resources and Environment, Provincial Public Health Office, District Office, District Public Health Office, local administration office, subdistrict office, village head office, and government health service center in the area where the project is located, or at any other locations easily accessed or seen by people. ${ }^{19}$

\section{c. Report Review}

When the draft EIA report is completed, it should be reviewed by the public and stakeholders to ensure that potential adverse effects could be prevented or mitigated. This process is addressed by the Notification which requires the project proponent to hold a public hearing. The project proponent must inform the ONREPP, NHCO and public of the hearing at least one month in advance.

${ }^{19} I d$.
The final draft of the report must be disclosed to the public at least 15 days before the date of hearing. The timing of hearing must be convenient to stakeholders and the public to come to express their views and they must have at least 3 hours in voicing their concerns which must account for not less than half of the entire time of the hearing. ${ }^{20}$

After the public hearing, the project proponent has duty to summarize all views expressed by the public and stakeholders as well as opinions or responses from the project proponent and relevant government agencies, and then submit them to the ONREPP for acknowledgement and the NHCO for further public distribution. ${ }^{21}$

\section{Steps to Submit and Review an EIA}

\section{Report}

Steps to submit and review an EIA report will be presented into two scenarios; one for a project that needs the Cabinet's approval, and the other for a project that needs permission for implementation.

\subsection{A Project that Needs the Cabinet's Approval}

If a project initiated by a government agency or state enterprise or jointly proposed by a government agency or state enterprise and a private investor is required by rule or regulation to obtain an approval from the Cabinet for its implementation, the submittal

${ }^{21} I d$. 
and review of its EIA report must comply with steps in Section 49 of the ECNEQA. First the project proponent (or a consultant hired by it) would have to prepare the report at the same time as the preparation of the feasibility study of the project. Secondly the EIA report would be submitted to the National Environment Board for consideration. To assist the Board in making a proper decision, it would appoint a committee of expert to read the report and forward its comments to the Board. The law does not state that the report must get an approval from the Board but instead the Board is required to make comments on the report. Thirdly the Board would submit the report with its comments to the Cabinet for consideration. Before rendering its approval or disapproval, the Cabinet may, if necessary, request a person or institute specializing in environmental impact assessment to study or prepare a report or make comments on this matter.

It should be noted that the EIA report accompanied by the National Environment Board could be used for five years in obtaining the Cabinet's approval. Another interesting point is that the ECNEQA does not provide timeframe for the Board and the Cabinet to make their decisions. As a result the Board and the Cabinet can spend time as much as they want. The reason why there is no timeframe, in the writer's view, seems to be that since projects in this group are usually large in size and need high investment, their implementation depends on the policy of the Cabinet, which must take several factors into account including political atmosphere.

\subsection{A Project that Needs Permission for Implementation}

In submitting an EIA report for a project that needs permission from or must notify a government agency before implementation, the project proponent would have to comply with steps prescribed by Section 50 of the ECNEQA. First, prior to the construction or operation of the project, the project proponent must submit the EIA report to both the competent authority vested with power to issue permission and the ONREPP, which also includes any other government agency designated by the National Environment Board. Pending the EIA report process, such a competent authority still cannot make a decision as to whether or not permission would be given to the implementation of the project.

Secondly after receiving the EIA report from the project proponent, the ONREPP would examine the completeness of the report and its attached documents within 15 days. If the application is not completed, it would be returned to the project proponent. If all the problems are rectified and the application is resubmitted, the ONREPP would read the contents of the report and make preliminary comments on it within 30 
days. Then the report and the comments would be forwarded to the Committee of Experts appointed by the National Environmental Board.

Thirdly after receiving the EIA report from the ONREPP, the Committee of Experts has 45 days to read the report and make a decision as to whether or not the report would be approved. If the decision is not made within the timeframe, it is deemed by law that the report is approved by the Committee. This legal assumption would certainly prompt the Committee to work fast and protect the interests of the project proponent not to be affected by the unnecessary delay process. If the Committee refuses to give an approval to the report, the project proponent would have 180 days to revise it in accordance with the Committee's instructions. In case that the project proponent does not revise the report within the deadline, he is deemed to terminate his application for the EIA report approval. However he is still entitled to reapply for such an approval. If he decides to revise the report and resubmit it within the timeframe, the Committee would have 30 days to decide to approve or not to approve the revised report. If the Committee fails to make a decision within timeframe, the revised report is deemed to be approved by the Committee. When the Committee refuses to give its approval to the revised report, the EIA process ends but the project proponent is still entitled to reapply for the EIA report approval.

Finally, when the Committee gives an approval to the EIA report, the ONREPP would inform the project proponent and the competent authority having power to issue permission to the project. After that the competent authority can make a decision as to whether to issue the permission. In case of issuing the permission, the conditions set up by the Committee in giving the approval to the EIA report would be incorporated into such permission, and the competent authority is obliged to enforce it as if it were issued under the competent authority's law.

It should be noted that once the Committee gives its approval to an EIA report, it would be valid for 5 years.

\section{Monitoring and Compliance}

As mentioned earlier, the conditions in the EIA reported approved by the Committee is deemed to be conditions under the law enforced by the government agency which gives permission to a project proponent. When the operation of the project begins, the project proponent must comply with such conditions. The ECNEQA stipulates that a project proponent has duty to prepare a report on compliance with what has been contained in the EIA report. The details of the report and how it should be prepared would be prescribed by the Ministry of Natural Resources and Environment with the approval of the National Environment Board. 
This report of compliance shall be submitted to the government agency which gives permission to such a project at least once a year.

Within 60 days after receiving the report of compliance in the previous paragraph, the government agency concerned must submit the report to the Provincial Office of Natural Resources and Environment in the area where the project is situated, or the ONREPP for projects in Bangkok. The ONREPP then would examine all the reports received, prepare another report of compliance which also includes comments and recommendations, and submit it to the National Environment Board at least once a year.

If it is found that a project proponent does not comply with the conditions set up by the Committee in the EIA report, the government agency giving permission to the project has duty to enforce such conditions under its law. The ONREPP has power to give instructions to such an agency to enforce its law. After receiving instruction from the ONREPP, the agency concerned must ensure compliance and report its actions to the ONREPP. However, the ONREPP has no power to force the project proponent to comply with the law.

The requirement of the preparation and submittal of the report of compliance would help to develop an environmental impact assessment process in Thailand since it would compile and analyze all the data and information concerning environment impact assessment across country. This would make the government understand what the problems in the environmental impact assessment are, and how to solve the problems.

\section{Possibility of Harmonizing ASEAN} Environmental Impact Assessment Law

After the official formation of $\mathrm{ASEAN}^{22}$ as an international organization in 2007 with the existence of ASEAN Community Blueprints, ${ }^{23}$ people in the region become closer together than before. The ASEAN Economic Community Blueprint aims to bring economic prosperity to the people by encouraging the formation of a single market and production base with free flow of goods, services, investment, capital, skilled labor. ${ }^{24}$ At the same time the ASEAN Socio-Cultural Community Blueprint would like to ensure, among other things, that the development must be sustainable and it does not cause environmental problems within and cross political boundaries. This is the reason why

\footnotetext{
${ }^{22}$ ASEAN stands for the Association of Southeast Asian Nations.

${ }^{23}$ The ASEAN Community Blueprints consist of the Economic Community Blueprint, Socio-Cultural Community Blueprint and Political-Security Community Blueprint.

${ }^{24}$ Association of Southeast Asian Nations, ASEAN Economic Community Blueprint, 2008.
} 
the harmonization of environmental policies and database is encouraged. ${ }^{25}$

The harmonization of environmental policies also includes, in this writer's view, the harmonization of environmental law as the law often contains policies and it can be used as a tool to implement the policies. The ASEAN harmonization of environmental law, especially law on environmental impact assessment, would have some advantages. First, it is supportive to the goals of the ASEAN Socio-Cultural Community Blueprint. Second, it would prevent the problem that investors tend to move away from countries with stringent environmental regulations to those having lax rules, which could lead to economic problems in the former countries and environmental injustice to people in the latter. Finally it would accommodate the free flow of service and investment since investors and those rendering service would face with similar law and regulations wherever they do business in the region.

At the same time the harmonization of environmental law would encounter some difficulties. First of all, some countries in the regions have far more advanced economic development than others which would to a certain extent lead to different goals and objectives of development usually reflected in their respective policies. Secondly due to

\footnotetext{
${ }^{25}$ Association of Southeast Asian Nations, ASEAN
} Socio-Cultural Community Blueprint, 2009. economic disparity and cultural, social and political differences in the region, the law on environmental protection and relevant regulations in each country are usually different from one another, let alone law enforcement.

However, the harmonization of environmental impact assessment law in this region might be possible since almost all the members of ASEAN have law on this matter. Such law in each country may be different in details of, for example, what size of project that needs an environmental impact assessment, what authority is responsible for giving an approval to an EIA report, or who is entitled to prepare an EIA report. However, this writer believes that some issues could be harmonized, particularly the issues that are quite universal. For instance, what data and information are essential to environmental impact assessment tend to be subject to relatively universal principles. With respect to issues that are less universal, the scope or framework of each issue could be discussed for harmonization and allow each state to develop its own law and regulation to govern the details of each issue. For example, the relevant ministries of ASEAN members may arrange a meet to discuss the scope of main issues to be harmonized such as the types and sizes of projects, the contents of an EIA report, who is entitled to prepare an EIA report, how compliance with an EIA report could be 
properly monitored and assessed and how the public and stakeholders could participate in an environmental impact assessment process.

\section{Conclusion}

The creation of ASEAN and the conclusion of its Community Blueprints is intended to bring peace, unity, economic prosperity and healthy environment to the region. In principle, there should be no political border for people and investors to render their services or do business within this area. However, in practice each member of ASEAN has its own law to regulate business and protect the environment, which could be an impediment to achieve the goal of being a single market and production base as well as common environmental policies.

This article uses an environmental impact assessment law in Thailand as an example of how this country applies its legal mechanism to predict potential adverse impacts from implementing a project and provide preventive and mitigation measures for such impacts. Under the relevant law, the Minister of Natural Resources and Environment has power to issue a ministerial notification prescribing what projects or activities to prepare an EIA report and obtain an approval from the authority concerned before its implementation. The ministerial notification also lays down principles and criteria for carrying out an environmental impact assessment, organizing public hearings and writing an EIA report. In addition, it contains provisions on how compliance with the law would be monitored and assessed by project operators.

The environmental impact assessment law in Thailand certainly shares some similarities and differences with that in other ASEAN countries but it is possible to expand their similarities and reduce their differences to achieve the common goals and objectives of ASEAN. This could be done by the joint

\section{References}

Association of Southeast Asian Nations, ASEAN Economic Community Blueprint, 2008.

Association of Southeast Asian Nations, ASEAN Socio-Cultural Community Blueprint, 2009.

Government Gazette, Volume 101, Chapter 184, Special Issue, page 1, December $12,1984$.

Government Gazette, Volume 127, Special Chapter 104 Ngor, page 34, August 31, 2010.

Government Gazette, Volume 129, Special Chapter 97 Ngor, page 1, June 20, 2012.

Government Gazette, Volume 134, Special Chapter 228 Ngor, page 5, September 18, 2017.

The ASEAN Community Blueprints consist of the Economic Community Blueprint, Socio-Cultural Community Blueprint and Political-Security Community Blueprint. 